\title{
INTERFERON-FREE THERAPY IS NOT A TRIGGER FOR HEPATOCELLULAR CARCINOMA IN PATIENTS WITH CHRONIC INFECTION WITH HEPATITIS C VIRUS
}

\author{
ANDRA-IULIA SUCEVEANU ${ }^{1^{*}}$, ANCA PANTEA STOIAN ${ }^{2 * *}$, LAURA MAZILU $^{1 \#}$, FELIX $^{2}$ \\ VOINEA $^{3 \#}$, RĂZVAN HAINĂROȘIE ${ }^{2 \#}$, CAMELIA CRISTINA DIACONU $^{2 \#}$, SILVIU PIȚURU ${ }^{2 \#}$, \\ CORNELIA NIȚIPIR $^{2 *}$, DUMITRU CRISTINEL BADIU ${ }^{2 \#}$, IULIANA CEAUȘU ${ }^{2 \#}$, ADRIAN PAUL \\ SUCEVEANU ${ }^{i \#}$
}

1"Ovidius” University, Faculty of Medicine, Internal Medicine Discipline, Gastroenterology Department, Constanța, Romania

2 "Carol Davila" University of Medicine and Pharmacy, Bucharest, Romania

3 "Ovidius" University, Faculty of Medicine, Urology Discipline, Constanța, Romania

*corresponding author: ancastoian@yahoo.com

\#All authors had equal scientific contribution and share first authorship

\begin{abstract}
The literature focused on data regarding the occurrence of hepatocellular carcinoma (HCC) after interferon (IFN)-free therapy is ambiguous. Researchers are preoccupied to find if the risk of developing liver cancer is related only to the therapy per se or it is influenced by a multitude of factors. We aimed to develop a local analysis of risk factors associated with HCC occurrence in patients with liver cirrhosis due to HCV (hepatitis C virus) infection treated with IFN-free therapy. We made an observational, retrospective study, between 2016 - 2019, on 188 cirrhotic patients with HCV infection, diagnosed, treated and followed-up by screening for HCC occurrence, using the recordings from the patient's charts available in the archive of the Gastroenterology Lab, “Aquamed” Clinic, Constanța County, Romania. We noted the demographic, lab, imagistic data and treatment procedures applied, comparing two groups of patients: the IFN-free therapy group - 89 patients and the standard IFN therapy group - 99 patients. As statistic method, we used the SAS Cox proportional hazards regression procedure, in order to calculate the HR (hazard ratio) and CI (confidence interval) $95 \%$ for each parameter studied as risk factor involved in HCC occurrence. In the unadjusted model, there was estimated an increased risk in HCC occurrence in IFN-free therapy group compared to standard IFN therapy group $(p=0.0341)$. After adjustment for age, gender, severity of the disease, (Child-Pugh classification) or complications, there was not a statistically significant difference between IFN-free therapy group or IFN therapy group in order to develop HCC (hazard ratio $=0.05, p=0.5038$ ). Our observational study, even if made on a small number of patients, confirms that IFN-free therapy is safe, the benefits obtained covering the risks. Our study results did not find a link between IFN-free therapy and HCC occurrence over the known risk of liver cirrhosis, when taking into account multiple features of disease prior to treatment onset.
\end{abstract}

\section{Rezumat}

Literatura axată pe datele referitoare la apariția carcinomului hepatocelular după terapia fără interferon (IFN) este ambiguă în acest moment. Cercetătorii sunt preocupați să stabilească dacă riscul de a dezvolta hepatocarcinom este legat numai de terapia per se sau este influențat de o multitudine de factori. În acest context, ne-am propus să facem o analiză locală a factorilor de risc asociați cu apariția HCC la pacienții cu ciroză hepatică datorată infecției cu virus hepatitic C (VHC) tratată fără IFN. Am efectuat un studiu observațional, retrospectiv, între anii 2016 - 2018 pe 188 de pacienți cu infecție cu VHC diagnosticați, tratați și urmăriți prin screening pentru apariția HCC, folosind înregistrările din diagramele pacientului, disponibile în arhiva Laboratorului de Gastroenterologie, Clinica „Aquamed”, județul Constanța, România. Am analizat datele demografice, de laborator și imagistice, precum și procedurile de tratament aplicate, comparând două grupuri de pacienți: grupul de terapie fără IFN - 89 pacienți și grupul de terapie IFN standard - 99 de pacienți. Ca metodă statistică am folosit procedura de regresie a riscurilor proporționale SAS Cox pentru a calcula intervalul de confidență HR și CI 95\% pentru fiecare parametru studiat ca factor de risc implicat în apariția HCC. În modelul neajustat, s-a estimat un risc crescut de apariție a HCC în grupul de tratament făă IFN în comparație cu grupul standard de terapie cu IFN (p=0,0341). După ajustarea pentru vârstă, sex, severitate a bolii (clasificarea ChildPugh) sau complicații, nu a existat o diferență semnificativă statistic între grupul de terapie fără IFN sau grupul de terapie IFN pentru a dezvolta HCC (raport hazard $=0,05, \mathrm{p}=0,5038$ ). Studiul nostru observațional, chiar dacă este făcut pe un număr mic de pacienți, are rezultate care confirmă faptul că terapia fără IFN este sigură, beneficiile obținute acoperind riscurile. Rezultatele studiului nostru nu găsesc o legătură între terapia fără IFN și apariția HCC peste riscul cunoscut de ciroză hepatică, atunci când se iau în considerare caracteristicile multiple ale bolii înainte de debutul tratamentului.

Keywords: IFN-free therapy, infection with hepatitis C virus, hepatocellular carcinoma 


\section{Introduction}

Researchers from Western Europe, Asia and North America warned in the last few years that the risk of hepatocellular carcinoma (HCC) in cirrhotic individuals may be higher after attaining interferon (IFN)-free hepatitis $\mathrm{C}$ virus (HCV) clearance versus clearance with an IFN-containing cure $[4,17,20]$. Initial univariate analysis found that IFN-free therapy was associated with a more than double risk to develop HCC $[6,8]$. Still, the elevated risk suggested initially seems to be attenuated after multivariate adjustment for baseline variables. It looks that the higher incidence of HCC following sustained virology response with IFN-free therapy relates to baseline risk factors and patient selection, and not to the use of IFN-free therapy per se [6]. On the background of this debate, we aimed to find if IFN-free therapy is a trigger for HCC occurrence, in patients with liver cirrhosis due to $\mathrm{HCV}$ chronic infection, and to detect the local risk factors involved in this oncologic pathology $[1,11,15,19]$.

\section{Materials and Methods}

\section{Study design: Patients}

We made an observational, retrospective study, between 2016 and 2019, on data provided from the files of 188 cirrhotic patients with HCV infection diagnosed, treated and followed-up by screening procedures according to AASLD (American Association for the Study of Liver Diseases) recommendations for HCC occurrence [2].

According to the treatment regimens used, patients were divided into two groups: the IFN-free therapy group - 89 patients, and standard IFN therapy group - 99 patients. Patients with HBV (hepatitis B virus)/HDV (hepatitis D virus) or HIV (human immunodeficiency virus) infections, autoimmune diseases, NAFLD (nonalcoholic fatty liver disease)/NASH (non-alcoholic steatohepatitis) proved by liver biopsy and genetic disorders with liver involvement (Wilson's Disease, alfa 1 anti-trypsin deficiency, haemochromatosis, type 1 diabetes etc.) have been excluded from the study. There were also excluded patients with suspected nodules in the liver at the treatment onset. IFN-free therapy was represented by combinations of different DAAs (direct acting antiviral agents). According to these combinations, most of our patients (77 patients $88 \%$ ) followed the regimen with ombitasvir, ritonavir, paritaprevir and daclatasvir for 12 weeks reimbursed by the state, and the rest of them (11 patients - 12\%), followed the treatment with ledipasvir plus sofosbuvir obtained by private resources, for the same period of time.

Methods

We used the recordings from the patient's charts available in the archive of Ambulatory Gastroenterology Department, "Aquamed" Clinic, Constanța County, Romania. We noted the demographic data (age, gender, provenience, BMI), the type of drug used, the duration of treatment, sustained virological response (SVR), the clinical and lab data recorded during the follow-up visits (every 6 months after the treatment finished), the abdominal ultrasonography results and the moment of HCC occurrence. Patients treated with IFN-based therapy followed the classical 24/48 weeks regimens with double therapy with IFN alfa- $2 \mathrm{a} / \mathrm{b}$ plus ribavirin, according to host and viral characteristics at baseline. Lab tests studied were: CBC (complete blood count), made with the automatic analyser Becton Dickinson $^{\circledR}$, using the principle of flow cytometry equipped with LASER semiconductor and hydrodynamic focusing, ALT (alanine aminotransferase)/AST (aspartate aminotransferase) tests, made by standardized kinetic method IFCC (International Federation for Clinical Chemistry) with or without pyridoxal phosphate, tests of liver insufficiency (albumin, PT (prothrombin time)), BT (bleeding time)/BD (blood collection) and tumour markers (alfa-fetoprotein, CEA-carcinoembryonic antigen), using analysers provided by Roche, Siemens and Beckman-Coulter Companies. Abdominal ultrasound examinations were done with General Electric LogiqS7 Expert equipment at every 6 months intervals during the follow-up period according to guidelines, focused on focal lesions detection into the liver parenchyma, accounting those with malignant potential. Clinical examination was done at every visit to gastroenterologist and features related to general status, BMI (body mass index), liver and spleen features, ascites were noted. Complications as variceal haemorrhages, encephalopathy, spontaneous peritonitis or kidney failure due to hepatorenal syndrome were also encountered.

Statistics

The GraphPad StateMate statistical package (San Diago, California, La Jolla, USA, www.graphpad.com) was used. SAS Cox proportional hazards regression procedure allowed us to calculate the risk for each parameter involved in HCC occurrence. The parameters estimates, the $p$ values (statistical significance $p<0.05$ ), and HR (hazard ratio) along with the $95 \% \mathrm{CI}$ intervals for each studied parameter were calculated. To provide strong evidence of our statistic results, we used the multivariate adjusted model.

\section{Results and Discussion}

The statistics was conducted in order to investigate differences in HCC occurrence adjusting for age, gender, severity of the disease, complications and history of IFN-free therapy. A total of 188 patients over 18-year-old and diagnosed with chronic hepatitis $\mathrm{C}$ infection, treated $(\mathrm{n}=89)$ or not $(\mathrm{n}=99)$ with IFN-free therapy, were followed until the HCC occurrence or up to 10 years. $62 \%(n=116)$ of patients were males and the mean age was 61.3 years for HCC 
FARMACIA, 2018, Vol. 66, 5

group and 55.7 for non-HCC group, ranging from 18 years to 70 years at treatment onset. There were 24 cases of HCC diagnosed among the 188 patients. Descriptive statistics shown in Table I classified the patients according to the main demographic and disease features at the beginning of the study period until HCC occurred.

Table I

Main characteristics of studied patients

\begin{tabular}{|l|c|c|}
\hline & HCC group (24 patients/188) & No HCC group (164 patients /188) \\
\hline Mean (SD) Age, years & $55.7(6.3)$ & $61.3(6.9)$ \\
\hline Gender (\%) & $16 / 24(66.66 \%)$ & $94 / 164(57.31 \%)$ \\
Male & $8 / 24(33.33 \%)$ & $70 / 164(42.68 \%)$ \\
\hline Female & $8 / 24(33.33 \%)$ & $40 / 164(24.39 \%)$ \\
\hline Child Pugh Class B/C & $10 / 24(41.66 \%)$ & $34 / 164(21.34 \%)$ \\
\hline Ascites & $5 / 24(20.83 \%)$ & $21(12.80 \%)$ \\
\hline IFN-free therapy & $10(11.23 \%)$ & $79(88.76 \%)$ \\
\hline IFN therapy & $14(14.14 \%)$ & $85(85.85 \%)$ \\
\hline
\end{tabular}

In the unadjusted model, there was estimated an increased risk in HCC occurrence in IFN-free therapy group compared to standard IFN therapy group $(\mathrm{p}=$ $0.0341)$. The short length of follow-up in the IFNfree therapy group (up to 2 years) compared to the long length of follow-up in IFN-therapy group makes believable the hypothesis that IFN-free therapy may be a bust for HCC occurrence. The rapid viral load decline produced by the potent antiviral drug used in combination and the abrupt cessation of liver inflammation are believed to adversely dampening cancer immune-surveillance activities that target the identifying and removal of cancer-prone hepatocytes, leading to a rapid and aberrant proliferation into the liver parenchyma and cancer occurrence [16, 18]. Using the univariate unadjusted model, our study results estimate that the age over 50 years old, male gender, Child Pugh B/C stages of the disease, ascites and IFN-free therapy were more often associated with HCC occurrence. Data are shown in Table II, along with the p-values.

Table II

The main risk factors associated with HCC occurrence using the unadjusted model

\begin{tabular}{|l|c|c|}
\hline \multicolumn{1}{|c|}{ Risk Factor } & Parameter Estimate & p-Value \\
\hline Age years & 0.17654 & 0.0001 \\
\hline Male gender & 0.37810 & 0.0002 \\
\hline Child-Pugh B/C & 0.65882 & 0.0003 \\
\hline Ascites & 0.11118 & 0.0001 \\
\hline IFN-free therapy & 0.08341 & 0.0341 \\
\hline
\end{tabular}

After this analysis, we concluded that there was a positive association between age over 50, male gender, Child-Pugh B/C stages, ascites and INF-free therapy with HCC occurrence. However, after adjustment for age, gender, severity of the disease (Child-Pugh classification) or complications, there was not a statistically significant difference between IFN-free therapy group or IFN therapy group in order to develop HCC (HR $=0.05, \mathrm{p}=0.5038)$ (Table III). In addition, adjusting for additional risk factors, patients treated with IFN-free therapy did not look to have an additional risk to develop HCC (Table IV). The HR estimates were used in order to strengths the analyse results. The analysis has shown that there is an $11.16 \%$ increase in the expected hazard relative ratio to develop HCC over the age of 50 (the expected hazard was 1.11 times higher in a person who is one year older than 50 to have HCC), holding the rest of parameters constant (gender, Child Pugh stage, ascites, IFN-free therapy). In addition, the expected hazard was 1.67 times higher in male gender compared to women, at the same age. The HR for decompensated disease or only for a single time ascites in the patient's history were 2.04 times higher, respectively 1.71 times higher in order to develop HCC, holding the age and gender constant, no matter of treatment used.

Table III

SAS Cox proportional hazards regression analyse estimating the main risk factors for HCC occurrence

\begin{tabular}{|l|c|c|}
\hline \multicolumn{1}{|c|}{ Risk Factor } & $\begin{array}{c}\text { Parameter } \\
\text { Estimate }\end{array}$ & $\begin{array}{c}\text { HR } \\
\text { (95\% CI for HR) }\end{array}$ \\
\hline Age $>50$ & 0.18342 & $1.11(1.086-1.789)$ \\
\hline Male gender & 0.45091 & $1.67(1.234-1.956)$ \\
\hline Child-Pugh B/C & 0.69786 & $2.04(1.034-1.777)$ \\
\hline Ascites & 0.11876 & $1.71(1.352-1.992)$ \\
\hline IFN-free therapy & 0.07231 & $0.05(0.004-1.023)$ \\
\hline
\end{tabular}

We considered as additional risk factors for HCC the high number of HCC in a short length of follow-up for IFN-free treated patients (up to 2 years of follow-up in IFN-free therapy group compared to up to 10 years in IFN group), genotype and viral load. We estimated the Cox proportional hazards regression model relating to the length of follow-up, genotype and viral load using the SAS Cox proportional hazards regression procedure. After adjusting for age, gender, severity of the disease and genotype, the viral load and the short length of follow-up period were not statistically significant associated with HCC occurrence in IFNfree therapy group compared to the standard treatment 
FARMACIA, 2018, Vol. 66, 5

group. We included in Table IV along with the hazard ratios, their $95 \%$ confidence intervals.

Table IV

SAS Cox proportional hazards regression analyse estimating the main risk factors for HCC occurrence

\begin{tabular}{|l|c|c|c|}
\hline \multicolumn{1}{|c|}{ Risk Factor } & Parameter Estimate & p-Value & HR (95\% CI for HR) \\
\hline Genotype 1b & 0.9321 & 0.003 & $1.012(1.006-1.201)$ \\
\hline Viral load & -0.08791 & 0.201 & $0.998(0.175-1.064)$ \\
\hline Length of follow-up & -0.01651 & 0.122 & $0.633(0.375-1.144)$ \\
\hline
\end{tabular}

$\mathrm{HCC}$ is the $5^{\text {th }}$ most common type of cancer globally [10]. The main concern regarding the issue is to decrease worldwide incidence of viral infections due to $\mathrm{B}, \mathrm{C}$ and $\mathrm{D}$ viruses by using curative treatments. We are witness of a new era in the treatment of hepatitis $\mathrm{C}$ virus chronic infection with the generically called IFN-free therapies. In cirrhotic patients, the survival rates are encouraging reaching, $92-96 \%$ according to TURQUOISE-2 TRIAL in genotype 1 ( $a$ and $b$ ) and 4 [14], 91\% in genotype 2, according to Phase III ASTRAL 2 trial [5] and over the expectations reaching 89 - 91\% in Phase III ALLY-3 trial [9, 12] and Phase III ASTRAL 3 trial [5] in hard-to-treat genotype 3 [18]. After a short period of follow-up, the main concern of physicians was directed to a possible increased risk of HCC induction by the DAAs treatments. Researchers warned recently about this high risk comparing to standard treatment cures, the hypothesis having major implications in HCV treatment management [7]. It looks that the rapid viral load decline and the rapid cessation of inflammatory liver process may lead to an altering of immune-surveillance activities and cancer occurrence by inefficient suppression of cancer promoters [3]. For example, one Scottish study recently published, claimed the significantly higher risk for $\mathrm{HCC}$ in patients treated with IFN-free treatment $(\mathrm{HR}=2.48,95 \%$ CI 1.14 - 5.37) [6]. Compared to our results, the mean period of follow-up was different from our study, 3.4 years in the Scottish study compared with 1.7 years for our IFN-free therapy group, due to low-resources settings, the reimbursed treatment with IFN-free therapy being available only for about 2 years and $12 \%$ of patients being treated by selfresources. Even if the period of follow-up was different, the overall rate of HCC occurrence was similar for both studies, around 2.53 events per 100 persons years for the referred study compared to 2.95 events per 100 persons - years. Still, to clarify this issue, more and more physicians focused on making ample statistic analyses. The previous Scottish study made on a high number of patients (875 patients) attending SVR (sustained virological response) after 12 weeks of different IFN-free therapies for $\mathrm{HCV}$ from 12 clinics, after multivariate adjustment for baseline variables, proved that no significant risk attributable to IFN-free therapy persisted $(\mathrm{HR}=1.15, \mathrm{p}=0.744)$, and other baseline factors were associated with increased HCC risk. The viral load and the length of follow-up period after treatment cure were not involved in HCC occurrence in our present study. After adjusting for age, gender, severity of the disease and genotype, the viral load and the short length of follow-up period were not statistically significant associated with HCC occurrence in IFN-free therapy group compared to standard treatment group. Regarding the rest of risk factors involved in HCC occurrence, the age over 50 years, male gender, Child-Pugh B/C stages, ascites and thrombocytopenia remained with the same pattern of involvement, as the literature confirms.

\section{Conclusions}

Our observational study, even if made on a small number of patients, confirms that IFN-free therapy is safe to use, the benefits obtained covering the risks. Our study results did not find a link between IFN-free therapy and HCC occurrence over the known risk of liver cirrhosis, when taking into account the multiple features of disease prior to treatment onset.

\section{References}

1. ANRS collaborative study group on hepatocellular carcinoma (ANRS CO22 HEPATHER, CO12 CirVir and $\mathrm{CO} 23$ CUPILT cohorts). Lack of evidence of an effect of direct-acting antivirals on the recurrence of hepatocellular carcinoma: Data from three ANRS cohorts. J Hepatol., 2016; 65: 734-740.

2. Bruix J, Sherman M, Management of Hepatocellular carcinoma: An update. AASLD, Practical Guideline. Hepatology, 2011; 53(3): 1020-1055.

3. Bu X, Xu F, Ma J, Wei L, Evaluation of cellular immune function and gastric tumour for biomarkers after early enteral nutrition. Farmacia, 2018; 66(4): 615-620.

4. Conti F, Buonfiglioli F, Scuteri A, Crespi C, Bolondi L, Caraceni P, Foschi FG, Lenzi M, Mazzella G, Verucchi G, Andreone P, Brillanti S, Early occurrence and recurrence of hepatocellular carcinoma in HCVrelated cirrhosis treated with direct-acting antivirals. J Hepatol., 2016; 65: 727-733.

5. Foster GR, Afdhal N, Roberts SK, Bräu N, Gane EJ, Pianko S, Lawitz E, Thompson A, Shiffman ML, Cooper C, Sofosbuvir and Velpatasvir for $\mathrm{HCV}$ Genotype 2 and 3 Infection. N Engl J Med., 2015; 373(27): 2608-2617.

6. Innes H, Barclay ST, Hayes PC, Fraser A, Dillon JF, Stanley A, Bathgate A, McDonald SA, Goldberg D, Valerio H, Fox R, Kennedy N, Bramley P, Hutchinson SJ, The risk of hepatocellular carcinoma in cirrhotic patients with hepatitis $\mathrm{C}$ and sustained viral response: Role of the treatment regimen al. J Hepatol., 2018; 68(4): 646-654. 
7. Hoza A, Moldovan C, Fărcaș DM, Pallag A, Nemeth S, Marc F, Comparative study of oral antidiabetic therapy and insulin therapy on hepatic steatosis in patients with type 2 diabetes mellitus. Farmacia, 2018; 66(4): 652-657.

8. Kozbial K, Moser S, Schwarzer R, Laferl H, Al-Zoairy R, Stauber R, Stättermayer AF, Beinhardt S, Graziadei I, Freissmuth C, Maieron A, Gschwantler M, Strasser M, Peck-Radosalvjevic M, Trauner M, Hofer H, Ferenci P, Unexpected high incidence of hepatocellular carcinoma in cirrhotic patients with sustained virologic response following interferon-free direct-acting antiviral treatment. J Hepatol., 2016; 65(4): 856-858.

9. Kowdley KV, Nelson DR, Lalezari JP, Box T, Gitlin N, Poleynard G, Rabinovitz M, Ravendhran N, Sheikh AM, Siddique A, Bhore R, Noviello S, Rana K, On-treatment HCV RNA as a predictor of sustained virological response in HCV genotype 3-infected patients treated with daclatasvir and sofosbuvir. Liver Int., 2016; 36(11): 1611-1618.

10. McGlynn KA, Jessica L, Petrick W, London T, Global epidemiology of hepatocellular carcinoma: an emphasis on demographic and regional variability. Clin Liver Dis., 2015; 19(2): 223-238.

11. Nahon P, Bourcier V, Layese R, Audureau E, Cagnot C, Marcellin P, Guyader D, Fontaine H, Larrey D, De Lédinghen V, Ouzan D, Zoulim F, Eradication of Hepatitis C Virus Infection in Patients With Cirrhosis Reduces Risk of Liver and Non-Liver Complications. Gastroenterology, 2016; 152(1): 142-156.

12. Nelson DR, Cooper JN, Lalezari JP, Lawitz E, Pockros PJ, Gitlin N, Freilich BF, Younes ZH, Harlan W, Ghalib R, All-oral 12-week treatmeant with daclatasvir plus sofosbuvir in patents with hepatitis $\mathrm{C}$ virus genotype 3 infection: ALLY-3 phase III study. Hepatology, 2015; 61(4): 1127-1135.

13. Pawlotsky JM, Panel members: Aghemo A, Back D, Dusheiko G, Forns X, Negro F, Puoti M, Sarrazin C, Correspondence: EASL EASL Recommendations on Treatment of Hepatitis C 2016. J Hepatol., 2017; 66: 153-194.
14. Poordad F, Hezode C, Trinh R, Kowdley KV, Zeuzem S, Agarwal K, Shiffman ML, Wedemeyer H, Berg T, Yoshida EM, Forns X, Lovell SS, Da Silva-Tillmann B, Collins CA, Campbell AL, Podsadecki T, Bernstein B, ABT-450/r-ombitasvir and dasabuvir with ribavirin for hepatitis C with cirrhosis. N Engl J Med., 2014; 370: 1973-1982.

15. Reig $M$, Mariño Z, Perelló $C$, Iñarrairaegui $M$, Ribeiro A, Lens S, Díaz A, Vilana R, Darnell A, Varela M, Sangro B, Calleja JL, Forns X, Bruix J, Unexpected high rate of early tumor recurrence in patients with HCV-related HCC undergoing interferon-free therapy. J Hepatol., 2016; 65: 719-726.

16. Serti E, Chepa-Lotrea X, Kim YJ, Keane M, Fryzek N, Liang TJ, Ghany M, Rehermann B, Successful Interferon-Free Therapy of Chronic Hepatitis $\mathrm{C}$ Virus Infection Normalizes Natural Killer Cell Function. Gastroenterology, 2015; 149: 190-200.

17. Tholey DM, Ahn J, Impact of Hepatitis C Virus Infection on Hepatocellular Carcinoma. Res Gastroenterol Clin North Am., 2015; 44(4): 761-773.

18. Kreefft K, Spaan M, van Oord G, Kreefft K, Hou J, Hansen BE, Janssen HL, de Knegt RJ, Boonstra A, Immunological Analysis during Interferon-Free Therapy for Chronic Hepatitis C Virus Infection Reveals Modulation of the Natural Killer Cell Compartment. J Infect Dis., 2016; 213: 216-223.

19. Yu ML, Huang CF, Yeh ML, Tsai PC, Huang CI, Hsieh MH, Hsieh MY, Lin ZY, Chen SC, Huang JF, Dai CY, Chuang WL, Time-degenerative factors and the risk of hepatocellular carcinoma after antiviral therapy among hepatic $\mathrm{C}$ virus patients: a model for prioritization of treatment. Clin Cancer Res., 2017; 23(7): 1690-1697.

20. Yu ML, Huang CF, The unexpected high risk of occurrence or recurrence of hepatocellular carcinoma after successful antiviral therapy with interferonfree direct-acting antivirals. Translat Cancer Res., 2016; 2: 1111-1115. 